\title{
Assessment of the usefulness of X-ray myelography and magnetic resonance myelography, performed with an open low-field device, in diagnosing perinatal preganglionic injuries of the brachial plexus
}

Jerzy Gosk ${ }^{1}$, Barbara Hendrich², Roman Wiącek ${ }^{1}$, Marek Sąsiadek2, ${ }^{2,3}$ Roman Rutowski ${ }^{1,4}$

1Department of Traumatology, Clinic of Traumatology and Hand Surgery, Wroclaw Medical University, Poland

2Department of General and Interventional Radiology and Neuroradiology, Academic Teaching Hospital, Wroclaw, Poland

${ }^{3}$ Chair of Radiology, Wroclaw Medical University, Poland

4Department of Biostructure, Department of Sport Medicine and Nutrition, University of Physical Education, Wroclaw, Poland

Submitted: 28 April 2011

Accepted: 1 January 2012

Arch Med Sci 2012; 8, 4: 678-683

DOI: 10.5114/aoms.2012.28597

Copyright @ 2012 Termedia \& Banach

\section{Abstract}

Introduction: The goal is to assess the usefulness of diagnostic imaging in diagnosing perinatal preganglionic injuries of the brachial plexus.

Material and methods: The clinical material included 40 children of both genders, aged 2 to 35 months. The authors analysed the results of diagnostic imaging examinations (myelography in 20 cases and magnetic resonance [MR] myelography in 20 cases), intraoperative view and clinical course.

Results: In 13 out of 40 (32.5\%) examined children, no evidence of avulsion of the roots of the spinal nerves was found either by diagnostic imaging or during the surgery. In 3 cases (7.5\%) with avulsed roots of the spinal nerves, the diagnostic imaging and intraoperative appearance were in agreement. Total agreement of the diagnostic imaging and intraoperative view was found in $40 \%$ of cases. In 9 patients (22.5\%) suspected avulsion of roots of the spinal nerves was not confirmed during the surgery. However, the further clinical course of the disease in these cases indicated high probability of avulsion of roots without their pull-out from the intervertebral foramens. In the remaining cases, the findings were as follows: false positive results $-7(17.5 \%)$, false negative results $-1(2.5 \%)$, results underestimating injury $-3(7.5 \%)$, results overestimating injury - 2 (5\%).

Conclusions: It was determined that the usefulness of pre-operative diagnostic imaging is limited. Due to the risk of occurrence of false positive and false negative results, final decisions concerning selection of the surgical technique must be based on the analysis of the intraoperative view and preoperative clinical symptoms.

Key words: brachial plexus, diagnostic imaging, spinal nerve root avulsion, perinatal injury.

\section{Introduction}

The goal of diagnostic imaging in diagnosing perinatal injuries of the brachial plexus is mainly to differentiate between preganglionic and post-

\section{Corresponding author:} Jerzy Gosk MD

Department of Traumatology, Clinic of Traumatology and Hand Surgery Wroclaw Medical University 213 Borowska 50-556 Wroclaw, Poland Phone: +48 717343800 Fax: +48 717343809 E-mail: chiruraz@am.wroc.pl 
ganglionic injuries of the brachial plexus [1-3]. Diagnostic imaging in children requires deep sedation or general anaesthesia because of the patients' uncontrollable movements $[1,4]$. Interpretation of the results may be more difficult than in adults because of pulsation of the cerebrospinal fluid and the necessity to assess the small area of interest [1]. Radiological protection of small patients excludes repeated exposure in the case of unsatisfactory quality of films. X-ray myelography is an invasive technique, requiring administration of the contrast agent into the spinal canal and general anaesthesia. Computed tomography (CT) myelography involves greater exposure to ionising radiation than in the case of $X$-ray myelography. Magnetic resonance imaging is a non-invasive method which does not involve exposure to ionising radiation. It is useful for diagnosing preganglionic injuries and it visualises peripheral parts of the brachial plexus [1, 5-8].

\section{Material and methods}

The clinical material included 40 children of both genders ( 21 boys and 19 girls) aged from 2 months to 35 months (mean age: 8.57 months) with perinatal injury of the brachial plexus, who were qualified for diagnostic imaging within pre-surgery diagnostics between 1998 and 2006. Initially conventional $X$-ray myelography of the cervical spine used to be performed after fluoroscopy-guided administration of the contrast agent into the spinal canal. Suboccipital puncture was applied in most cases and lumbar puncture in a few cases. Two to ten $\mathrm{ml}$ of contrast of concentration of $270 \mathrm{mg} \mathrm{l} / \mathrm{ml}$ (metrizamide) or $240 \mathrm{l} / \mathrm{ml}$ (monomer iohexol and dimer iotrolan) were administered, the quantity of used contrast agent depending on the child's weight. Only anterio-posterior films of the cervical spine were made, including the cervical-thoracic border zone (Figure 1). For the same reason CT myelography used to be performed (with TUR 800 or SIREGRAF device) immediately after the myelography only in the cases of insufficient quality of radiographs. Later, MR myelography (myelo-MRI) examination, as an entirely non-invasive method, replaced X-ray myelography completely. Myelo-MRI was performed with a low-field device (low-field open device: MR OUTLOOK PREVIEW 0,23 T - Marconi Medical Sytrunk). The fast spinecho 2D (FSE 2D) sequence was applied with the following parameters: TR 5000 ms, TE 308 ms, FA $90^{\circ}$, slice thickness $3.0 / 3.5 \mathrm{~mm}$, partition number 6 or 12, acquisition time 4 and 8 min respectively. Longitudinal and transverse MIP reconstructions were performed. A total of $20 \mathrm{X}$-ray myelographic examinations (supplemented by CT myelography in two cases) and 20 myelo-magnetic resonance imaging (MRI) examinations were performed. Images studies (X-ray myelography, MRI myelography) were evaluated by two neuroradiologists (B.H., M.S.) who were blinded to all clinical information (side of injury, clinical history, results of neurological examination, results of surgery and intraoperative findings). The diagnostic imaging results and intraoperative view were analysed. In the cases of discrepancies between the result of a diagnostic imaging study and intraoperative view, restoration of the function dependent on localization of the point suspected of preganglionic injury was assessed (applying commonly accepted evaluation scales) [9]. The postoperative follow-up ranged from 3 to 11 years. The sensitivity and specificity of diagnostic images were established.

\section{Statistical analysis}

The statistical analysis was performed using the program Statistica 8.0. The differences between X-ray myelography and MR myelography were assessed by $\chi^{2}$ test.

\section{Results}

The analysis revealed 13 normal results (no evidence of spinal nerve root avulsion) of diagnostic imaging (8 X-ray myelographic examinations and 5 myelo-MRI studies), and in all those cases intra-

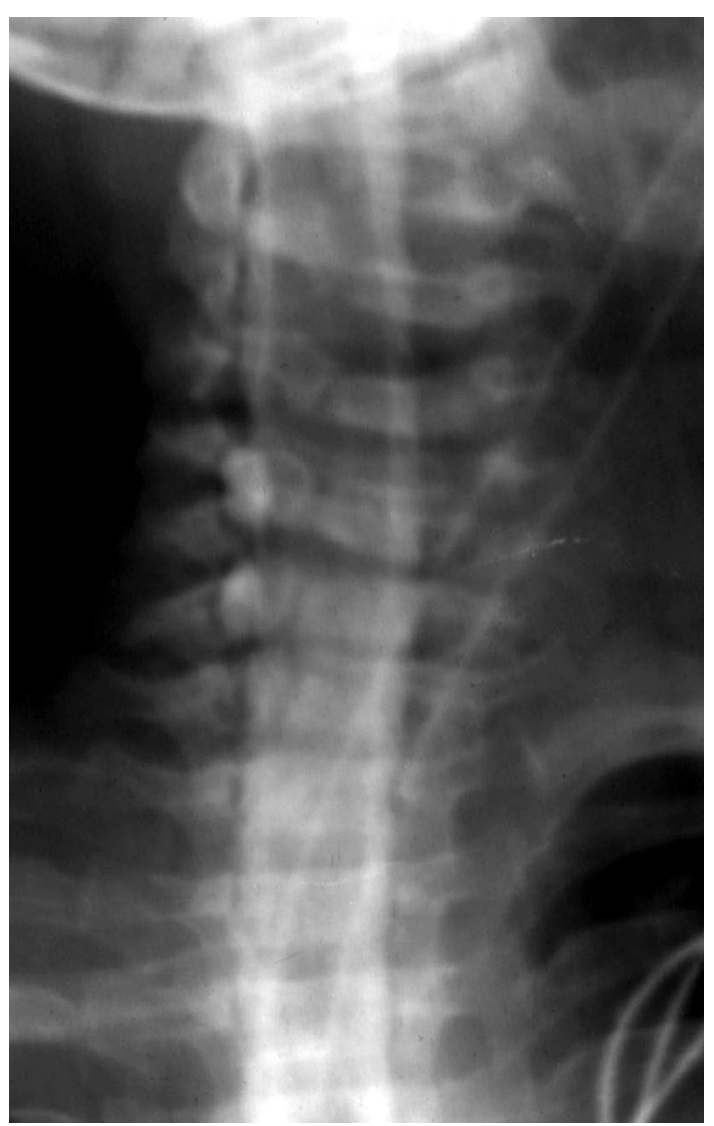

Figure 1. Myelography in child (anaesthetic accessories are visible); pseudomeningoceles on the right side level $\mathrm{C5/C6}$ and $\mathrm{C6/C7}$ 
Table I. Analysis of the cases of agreement of the diagnostic imaging and intraoperative view

\begin{tabular}{|c|c|c|c|c|c|}
\hline No. & $\begin{array}{l}\text { Clinical } \\
\text { appearance } \\
\text { of the injury }\end{array}$ & $\begin{array}{l}\text { Type of } \\
\text { diagnostic } \\
\text { imaging }\end{array}$ & $\begin{array}{l}\text { Result of the } \\
\text { diagnostic } \\
\text { imaging }\end{array}$ & Intraoperative view & Interpretation \\
\hline 1 & Upper & Myelography & $\begin{array}{l}\text { No evidence } \\
\text { of avulsion }\end{array}$ & $\begin{array}{l}\text { Rupture of C5, compression } \\
\text { of C } 6 \text { and upper trunk }\end{array}$ & Agreement of results \\
\hline 2 & Upper-middle & Myelography & $\begin{array}{l}\text { No evidence } \\
\text { of avulsion }\end{array}$ & $\begin{array}{l}\text { Compression of the upper } \\
\text { and middle trunk }\end{array}$ & Agreement of results \\
\hline 3 & Upper-middle & Myelography & $\begin{array}{l}\text { No evidence } \\
\text { of avulsion }\end{array}$ & $\begin{array}{l}\text { Neuroma of the continuity } \\
\text { of the upper and middle trunk }\end{array}$ & Agreement of results \\
\hline 4 & Upper-middle & Myelography & $\begin{array}{l}\text { No evidence } \\
\text { of avulsion }\end{array}$ & $\begin{array}{l}\text { Rupture of the upper trunk, } \\
\text { compression of the middle trunk }\end{array}$ & Agreement of results \\
\hline 5 & Upper-middle & Myelography & $\begin{array}{l}\text { No evidence } \\
\text { of avulsion }\end{array}$ & $\begin{array}{l}\text { Compression of the upper } \\
\text { and middle trunk }\end{array}$ & Agreement of results \\
\hline 6 & Complete & Myelography & $\begin{array}{l}\text { No evidence } \\
\text { of avulsion }\end{array}$ & $\begin{array}{l}\text { Neuroma of the continuity } \\
\text { of the upper and middle trunk, } \\
\text { compression of the lower trunk }\end{array}$ & Agreement of results \\
\hline 7 & Complete & Myelography & $\begin{array}{l}\text { No evidence } \\
\text { of avulsion }\end{array}$ & $\begin{array}{l}\text { Compression of the trunks } \\
\text { of the plexus }\end{array}$ & Agreement of results \\
\hline 8 & Complete & Myelography & $\begin{array}{l}\text { No evidence } \\
\text { of avulsion }\end{array}$ & $\begin{array}{l}\text { Rupture of the upper trunk, } \\
\text { compression of the middle } \\
\text { and lower trunk }\end{array}$ & Agreement of results \\
\hline 9 & Complete & Myelography & $\begin{array}{l}\text { Avulsion } \\
\text { of } C 6, \mathrm{C} 7\end{array}$ & $\begin{array}{l}\text { Rupture of C5, avulsion } \\
\text { of C } 6 \text { and C7, compression } \\
\text { of the lower trunk }\end{array}$ & Agreement of results \\
\hline 10 & Upper-middle & Myelo-MRI & $\begin{array}{l}\text { No evidence } \\
\text { of avulsion }\end{array}$ & $\begin{array}{l}\text { Compression of the upper } \\
\text { and middle trunk }\end{array}$ & Agreement of results \\
\hline 11 & Upper-middle & Myelo-MRI & $\begin{array}{l}\text { No evidence } \\
\text { of avulsion }\end{array}$ & $\begin{array}{l}\text { Compression of the upper } \\
\text { and middle trunk }\end{array}$ & Agreement of results \\
\hline 12 & Complete & Myelo-MRI & $\begin{array}{l}\text { No evidence } \\
\text { of avulsion }\end{array}$ & $\begin{array}{l}\text { Compression of the trunks } \\
\text { of the plexus }\end{array}$ & Agreement of results \\
\hline 13 & Complete & Myelo-MRI & $\begin{array}{l}\text { No evidence } \\
\text { of avulsion }\end{array}$ & $\begin{array}{l}\text { Neuroma of the continuity } \\
\text { of the upper and middle trunk, } \\
\text { compression of the lower trunk }\end{array}$ & Agreement of results \\
\hline 14 & Complete & Myelo-MRI & $\begin{array}{l}\text { No evidence } \\
\text { of avulsion }\end{array}$ & $\begin{array}{c}\text { Rupture of } \mathrm{C} 5, \mathrm{C} 6, \mathrm{C} 7 \text {, } \\
\text { compression of the lower trunk }\end{array}$ & Agreement of results \\
\hline 15 & Complete & Myelo-MRI & $\begin{array}{l}\text { Avulsion } \\
\text { of C6 }\end{array}$ & $\begin{array}{l}\text { Rupture of } \mathrm{C} 5, \mathrm{C7} \text {, avulsion of C6, } \\
\text { compression of the lower trunk }\end{array}$ & Agreement of results \\
\hline 16 & Complete & Myelo-MRI & $\begin{array}{l}\text { Avulsion } \\
\text { of } C 7, \text { C } 8\end{array}$ & $\begin{array}{l}\text { Rupture of the upper trunk, } \\
\text { avulsion of C } 7, \mathrm{C} 8, \\
\text { compression of Th1 }\end{array}$ & Agreement of results \\
\hline
\end{tabular}

operatively no signs of a preganglionic injury were observed. In a further 3 cases avulsion of roots of the spinal nerves was found in diagnostic imaging and confirmed intraoperatively. These cases concerned avulsion of the roots of spinal nerve $\mathrm{C} 6$ and C7 (myelography), avulsion of the roots of spinal nerve C6 (MR myelography), and avulsion of roots of spinal nerve C7 and C8 (MRI myelography) Table I. Discrepancies between results of the myelographic studies and intraoperative view are discussed in Tables II and III. The comparison of the efficacy of diagnostic imaging (X-ray myelography and MRI myelography) in relation to the intraoperative view is shown in Table IV.
In 9 cases, the further clinical course indicated the possibility of the potential avulsion of roots of the spinal nerves at C8-Th1, as suggested by the diagnostic imaging studies. However, no clear evidence of avulsion was found intra-operatively in these cases. The patients' data are shown in Table V.

The sensitivity of X-ray myelography was $78 \%$, and the specificity was $93 \%$. The sensitivity of MRI myelography was $64 \%$, and the specificity was $94 \%$.

\section{Discussion}

The diagnostic studies have been performed only in children qualified for surgical treatment based on the clinical view of injury. Twenty-eight of 40 chil- 
Assessment of the usefulness of X-ray myelography and magnetic resonance myelography, performed with an open low-field device, in diagnosing perinatal preganglionic injuries of the brachial plexus

Table II. Analysis of discrepancies between the myelo-MRI result and intraoperative view considering further clinical course

\begin{tabular}{|c|c|c|c|c|c|}
\hline No. & $\begin{array}{c}\text { Clinical } \\
\text { appearance } \\
\text { of the injury }\end{array}$ & $\begin{array}{l}\text { Diagnostic } \\
\text { imaging }\end{array}$ & $\begin{array}{c}\text { Intraoperative } \\
\text { view }\end{array}$ & $\begin{array}{l}\text { Return } \\
\text { of function }\end{array}$ & Interpretation \\
\hline 1 & Upper-middle & Avulsion of C6 & Rupture of the upper trunk & Improved function & False positive result \\
\hline 2 & Upper-middle & Avulsion of Th1 & No evidence of avulsion & Normal function & False positive result \\
\hline 3 & Upper-middle & Avulsion of $\mathrm{C} 7, \mathrm{C} 8$ & $\begin{array}{l}\text { Avulsion of } \mathrm{C} 7 \text {; } \mathrm{C} 8 \\
\text { in the foramen }\end{array}$ & Improved function & Overestimated result \\
\hline 4 & Upper-middle & $\begin{array}{l}\text { Avulsion of } \mathrm{C} 6, \mathrm{C7} \\
\text { and possibly } \mathrm{C5}\end{array}$ & No evidence of avulsion & Improved function & False positive result \\
\hline 5 & Complete & Avulsion of C8, Th1 & $\begin{array}{l}\text { Avulsion of } \mathrm{C} 7 \text {; } \mathrm{C} 8 \text {, Th1 } \\
\text { in the foramens }\end{array}$ & Poor function & Possible avulsion \\
\hline 6 & Complete & Avulsion of C8, Th1 & $\begin{array}{l}\text { Avulsion of } \mathrm{C} 7 \text {; } \mathrm{C} 8 \text {, Th1 } \\
\text { in the foramens }\end{array}$ & Poor function & Possible avulsion \\
\hline 7 & Complete & Avulsion of C8, Th1 & No evidence of avulsion & Poor function & Possible avulsion \\
\hline 8 & Complete & Avulsion of Th1 & No evidence of avulsion & Poor function & Possible avulsion \\
\hline 9 & Complete & $\begin{array}{l}\text { Avulsion of } \mathrm{C} 5 \\
\text { C6, C7, C8 }\end{array}$ & $\begin{array}{l}\text { Avulsion of } \mathrm{C} 6, \mathrm{C} 7, \mathrm{C} 8 \text {; } \\
\quad \text { rupture of } \mathrm{C} 5\end{array}$ & Improved function & Overestimated result \\
\hline 10 & Complete & Avulsion of $\mathrm{C} 6, \mathrm{C7}$ & Avulsion of C5, C6, C7 & Poor function & Underestimated result \\
\hline 11 & Complete & Avulsion of $\mathrm{C} 7, \mathrm{C} 8$ & $\begin{array}{l}\text { Avulsion of } \mathrm{C} 7 \text {; } \mathrm{C} 8 \\
\text { in the foramen }\end{array}$ & No data & No data \\
\hline 12 & Complete & Avulsion of C8, Th1 & No evidence of avulsion & Poor function & Possible avulsion \\
\hline 13 & Complete & $\begin{array}{c}\text { Avulsion } \\
\text { of } \mathrm{C} 6, \mathrm{C} 7, \mathrm{C} 8\end{array}$ & $\begin{array}{c}\text { Avulsion } \\
\text { of C5, C6, C7, C8, Th1 }\end{array}$ & Poor function & Underestimated result \\
\hline
\end{tabular}

Table III. Analysis of discrepancies between the X-ray myelography result and intraoperative view considering further clinical course

\begin{tabular}{|c|c|c|c|c|c|}
\hline No. & $\begin{array}{c}\text { Clinical } \\
\text { appearance } \\
\text { of the injury }\end{array}$ & $\begin{array}{l}\text { Diagnostic } \\
\text { imaging }\end{array}$ & $\begin{array}{c}\text { Intraoperative } \\
\text { view }\end{array}$ & $\begin{array}{l}\text { Return } \\
\text { of function }\end{array}$ & Interpretation \\
\hline 1 & Upper-middle & Avulsion of C8 & No evidence of avulsion & Normal function & False positive result \\
\hline 2 & Complete & $\begin{array}{l}\text { No evidence } \\
\text { of avulsion }\end{array}$ & Avulsion of C7 & Improved function & False negative result \\
\hline 3 & Complete & Avulsion of C8, Th1 & No evidence of avulsion & Restored function & False positive result \\
\hline 4 & Complete & Avulsion of Th1 & No evidence of avulsion & Restored function & False positive result \\
\hline 5 & Complete & Avulsion of $\mathrm{C} 8$ & No evidence of avulsion & Poor function & Possible avulsion \\
\hline 6 & Complete & Avulsion of C8 & $\begin{array}{l}\text { Avulsion of } \mathrm{C} 7 \text {; } \mathrm{C} 8 \\
\text { in the foramen }\end{array}$ & Poor function & Possible avulsion \\
\hline 7 & Complete & Avulsion of C7, Th1 & No evidence of avulsion & Poor function (hand) & Possible avulsion of Th1 \\
\hline 8 & Complete & Avulsion of C6, Th1 & $\begin{array}{l}\text { Rupture of the upper trunk; } \\
\text { Th1 in the foramen }\end{array}$ & Restored function & False positive result \\
\hline 9 & Complete & Avulsion of C7, C8 & Avulsion of $\mathrm{C} 7, \mathrm{C} 8$, Th1 & Poor function & Underestimated result \\
\hline 10 & Complete & $\begin{array}{l}\text { Avulsion } \\
\text { of } \mathrm{C} 7, \mathrm{C} 8, \mathrm{Th} 1\end{array}$ & $\begin{array}{l}\text { Avulsion of } \mathrm{C} 7 \text {; } \mathrm{C} 8 \text {, Th1 } \\
\text { in the foramens }\end{array}$ & Poor function & Possible avulsion \\
\hline 11 & Complete & $\begin{array}{c}\text { Avulsion } \\
\text { of } \mathrm{C} 7, \mathrm{C} 8 \text {, Th1 }\end{array}$ & $\begin{array}{l}\text { Avulsion of } \mathrm{C} 6, \mathrm{C} 7, \mathrm{C} 8 \text {; Th1 } \\
\text { in the foramen }\end{array}$ & Poor function & Discrepancy of levels \\
\hline
\end{tabular}

dren showed total injuries of the brachial plexus (C5-Th1), while 11 had symptoms of upper-middle lesions of the brachial plexus (C5-C7). Indications for surgical treatment in perinatal brachial plexus palsy include not only preganglionic injuries, but also postganglionic lesions. In this type of injury different degrees of neural element lesions according to Sunderland's scale are observed. The absence of 
Table IV. The comparison of efficacy of diagnostic imaging (X-ray myelography and MRI myelography) in relation to intraoperative view

\begin{tabular}{|c|c|c|c|c|}
\hline Results of diagnostic imaging & $\begin{array}{c}\text { All cases } \\
(n=40)\end{array}$ & $\begin{array}{c}\text { X-ray } \\
\text { myelography } \\
(\mathrm{XM}) \\
(n=20)\end{array}$ & $\begin{array}{c}\text { MRI } \\
\text { myelography } \\
(\text { MRI) } \\
(n=20)\end{array}$ & $\begin{array}{c}\text { Statistical } \\
\text { significance } \\
\text { (XM/MRI) }\end{array}$ \\
\hline Consistent & $16(40 \%)$ & $9(45 \%)$ & $7(35 \%)$ & $p=N S$ \\
\hline Without avulsion & 3 & 8 & 5 & \\
\hline With avulsion & 3 & 1 & 2 & \\
\hline Inconsistent & $24(60 \%)$ & $11(55 \%)$ & $13(65 \%)$ & $p=N S$ \\
\hline Discrepancy of levels & 1 & 1 & 0 & \\
\hline False positive results & 7 & 4 & 3 & \\
\hline False negative results & 1 & 1 & 0 & \\
\hline Results overestimating injury & 2 & 0 & 2 & \\
\hline Results underestimating injury & 3 & 1 & 2 & \\
\hline Possible avulsion based on long-term clinical observation & 9 & 4 & 5 & \\
\hline Absence of clinical examination & 1 & 0 & 1 & \\
\hline
\end{tabular}

Table V. Data of patients with suspected avulsion of roots of the lower spinal nerves seen in diagnostic imaging

\begin{tabular}{|c|c|c|c|c|}
\hline No. & $\begin{array}{c}\text { Avulsion suspected } \\
\text { in the diagnostic imaging }\end{array}$ & $\begin{array}{l}\text { Hand function } \\
\text { in Al-Qattan scale }\end{array}$ & Horner syndrome & Improvement in EMG \\
\hline 1 & C8, Th1 & 1 & - & None \\
\hline 2 & C8, Th1 & 2 & - & Improvement \\
\hline 3 & C8, Th1 & 2 & + & Improvement \\
\hline 4 & Th1 & 1 & + & Improvement \\
\hline 5 & C8, Th1 & 1 & + & None* \\
\hline 6 & $\mathrm{C8}$ & 2 & - & Improvement \\
\hline 7 & $\mathrm{C} 8$ & 2 & + & None \\
\hline 8 & Th1 & 1 & - & None $^{*}$ \\
\hline 9 & C8, Th1 & 2 & - & None \\
\hline
\end{tabular}

*temporary improvement in the EMG study, then stationary condition

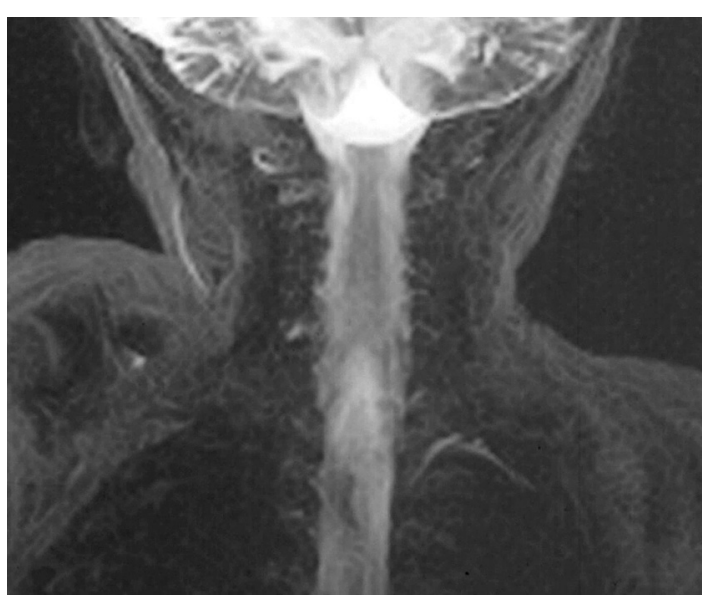

Figure 2. Difficulties in counting levels in small children; MRI image: very small pseudomeningocele laterally to spinal canal (right side) - suspected avulsion of roots of spinal nerve C6 spinal nerve root avulsion in diagnostic images is not a factor excluding the necessity of surgical intervention [10-14].

A main symptom suggesting spinal nerve root avulsion in myelography is a traumatic pseudomeningocele, manifested as an additional enhancement of the signal seen laterally from the dural sac. A pseudomeningocele may be a sign of avulsion of roots of the spinal nerve, but in X-ray myelography it does not constitute a final proof of this injury. Even if the nerve roots' function is maintained, it may be present in $13-18 \%$ of cases [12, 14, 15]. Myelographic study involves a risk of side effects. In some cases, aseptic meningitis and short-term convulsions after administration of the contrast agent were observed [11].

The magnetic resonance imaging with myelography option (myelo-MRI) may reveal avulsion with or without presence of traumatic pseudomeningocele [13]. Pseudomeningocele may be an isolated 
injury or may be associated with an injury to roots of the spinal nerves, including or not their avulsion from the spinal cord [1]. Therefore, when interpreting the results of the imaging studies, one must bear in mind the risk of false positive and false negative results as compared to the intraoperative view $[5,13]$. Discrepancies may also concern the level of injury [16]. Difficulties with determination of the level of injury in children may occur due to the variable degree of ossification of vertebrae in small children, which causes level calculation mistakes (Figure 2).

While performing our diagnostic imaging, continuity of roots of the spinal nerves was not assessed, because their contour was not visualised. In interpretation of X-ray myelography and myelo-MRI results, the following indirect symptoms of nerve root avulsion were considered: presence or absence of pseudomeningocele, location of pseudomeningocele suggesting the level of root injury, location of pseudomeningocele in relation to intravertebral foramens and spinal canal, dimension of pseudomeningocele, compression of the dural sac and spinal cord or its absence. The other uncertain myelographic symptoms of nerve root avulsion were deformation or irregular contour of the dural sac, lack of visualisation of nerve roots in the dural sac and intravertebral foramens, and presence of tiny contrast addition which may suggest nerve sheath damage. Analysis of the diagnostic imaging studies performed before the surgery revealed the following discrepancies between their results and the intraoperative view: false positive results, false negative results, discrepancy of levels, results underestimating the injury, and results overestimating the injury. There were also cases in which avulsion of roots of spinal nerve C 8 and Th1 was suspected in diagnostic imaging studies, but it was not confirmed intraoperatively. In these children poor improvement of hand function was found as assessed by the Al-Qattan scale [9] (Table V). However, only in 4 out of the 9 children was Horner syndrome observed. If we assume that a complete avulsion of roots of spinal nerves C8 and Th1 is associated with this syndrome, then in the remaining children it was either not avulsion injury or only partial avulsion.

The statistical analysis performed in our material did not reveal significant differences in efficacy of X-ray myelography and MRI myelography in diagnosis of perinatal brachial plexus palsy. The sensitivity and specificity of diagnostic images in our material were similar to those reported in the literature $[1,2,5,7]$. Analysis of the performed imaging studies revealed their limited usefulness in some respects. In some institutions, there is a tendency to limit indications to preoperative diagnostic imaging, especially CT myelography [10, 17]. Currently, the magnetic resonance imaging technique with high-field devices (1.5 T) applying additional sequences (e.g. FIESTA) allows for very precise assess- ment of the course of roots of the spinal nerves. As this is a non-invasive study which does not apply radiation, it should be the method of choice in children. One may hope that with further development of MRI techniques, the usefulness of imaging in diagnostics of preganglionic injury of the brachial plexus will increase.

In conclusion, results of diagnostic imaging studies should be included in comprehensive preoperative assessments, but final decisions concerning surgical technique should be based on the clinical and intraoperative view.

\section{References}

1. Birchansky S, Altman N. Imaging the brachial plexus and peripheral nerves in infants and children. Sem Pediatr Neurol 2000; 7: 15-25.

2. Chow BC, Blaser S, Clarke HM. Predictive value of computed tomographic myelography in obstetrical brachial plexus palsy. Plast Reconstr Surg 2000; 106: 971-7.

3. Hendrich B, Sąsiadek M, Turek T, Bem Z. Porównanie wartości mielografii-MR i mielografii rentgenowskiej w diagnostyce urazowych uszkodzeń splotu ramiennego. Pol J Radiol 2003; 68: 23-9.

4. Hazama A, Kinouchi K, Kitamura S, Fukumitsu K. Brachial plexus birth injuries: anaesthesia for surgical nerve reconstruction and preoperative myelography and computed tomographic myelography. Paediatr Anaesth 1999; 9: 403-7.

5. Abbott R, Abbott M, Alzate J, Lefton D. Magnetic resonance imaging of obstetrical brachial plexus injuries. Childs Nerv Syst 2004; 20: 720-5.

6. Hayashi N, Yamamoto S, Okubo T, et al. Avulsion injury of cervical nerve roots: enhanced intradural nerve roots at MR imaging. Radiology 1998; 206: 817-22.

7. Hems TE, Birch R, Carlstedt T. The role of magnetic resonance imaging in the management of traction injuries to the adult brachial plexus. J Hand Surg Br 1999; 24: 550-5.

8. Maravilla KR, Bowen BC. Imaging of the peripheral nervous system: evaluation of peripheral neuropathy and plexopathy. AJNR Am J Neuroradiol 1998; 19: 1011-23.

9. Al-Qattan MM. Assessment of the motor power in older children with obstetric brachial plexus palsy. I Hand Surg 2003; 28: 46-9.

10. Haerle M, Gilbert A. Management of complete obstetric brachial plexus lesions. J Pediatr Orthop 2004; 24: 194-200.

11. Kay SP. Obstetrical brachial palsy. Br J Plast Surg 1998; 51 : 43-50.

12. Piatt JH Jr. Birth injuries of the brachial plexus. Pediatr Clin North Am 2004; 51: 421-40.

13. Slooff AC. Obstetric brachial plexus lesions and their neurosurgical treatment. Microsurgery 1995; 16: 30-4.

14. van Ouwerkerk WJ, van der Sluijs JA, Nollet F, Barkhof F, Slooff AC. Management of obstetric brachial plexus lesions: state of the art and future developments. Childs Nerv Syst 2000; 16: 638-44.

15. Eng GD, Binder H, Getson P, O’Donnell R. Obstetrical brachial plexus palsy (OBPP) outcome with conservative management. Muscle Nerve 1996; 19: 884-91.

16. Sąsiadek M, Hendrich B, Pielka S, Rutowski R. Diagnostic efficiency of cervical myelography in the traumatic injuries of the brachial plexus. Pol J Radiol 1991; 55: 88-91.

17. Strömbeck C, Krumlinde-Sundholm L, Forssberg H. Functional outcome at 5 years in children with obstetrical brachial plexus palsy with and without microsurgical reconstruction. Dev Med Child Neurol 2000; 42: 148-57. 